\title{
Chapter 15 \\ Microbial Interactions and Activities Affecting Sago Palm Growth
}

\author{
Koki Toyota
}

\begin{abstract}
Microbes are ubiquitous soil inhabitants. Both aboveground and belowground parts of plants are associated with diverse and abundant microbes. Such microbes have positive and negative impacts on the plant productivity. Biological nitrogen fixation (BNF) is such a beneficial interaction. To reveal BNF by freeliving bacteria in sago palm, different parts (root, rachis, petiole, leaflet, bark, pith, and extracted starch) were collected in the Philippines, and their nitrogen-fixing ability was measured. Almost all the samples showed positive nitrogen fixation. Then, nitrogen-fixing bacteria (NFB) were isolated, belonging to different genera, such as Klebsiella sp., Pantoea sp., Burkholderia sp., Stenotrophomonas sp., and Bacillus sp. All the isolates preferred simple carbon compounds, like glucose, sucrose, and mannitol, as their substrates for nitrogen fixation, while they showed very low activity in starch, pectin, and hemicellulose media. When NFB were cocultured in such a medium with the polymer-degrading bacteria, nitrogen-fixing ability was markedly increased. Stimulatory effects were observed in Rennie medium by co-inoculation of NFB and indigenous bacterial consortia isolated from sago palm samples. These results indicate that complex microbial interactions may increase in situ nitrogen fixation and contribute to nitrogen nutrition in sago palm. This chapter also introduces characteristics of nitrogen-fixing bacteria and amounts of BNF in palm trees in recent studies.
\end{abstract}

\subsection{Microbial Activities Relating to Plant Growth}

Microbes exist everywhere, especially in soil. A classic report in Russia revealed that bacteria are a ubiquitous soil inhabitant, and total bacterial numbers are stable across quite diverse soil environments, from dry and desert steppe through meadow steppe, from forest meadow to taiga, and from 1200 to $3600 \mathrm{~m}$ above sea level (Mishustin and Mirsoeva 1968). By contrast, they found that specific groups of bacteria favor certain habitats and show large fluctuations depending on time and

K. Toyota $(\bowtie)$

Tokyo University of Agriculture and Technology, Koganei, Tokyo, Japan

e-mail: kokit@cc.tuat.ac.jp 
location. For example, spore-forming bacteria, enumerated as heat-tolerant ones, showed large fluctuations in their numbers, ranging from 0.01 to $1.2 \times 10^{6} \mathrm{~g}^{-1}$ soil (more than 100 times difference) depending on the sampling sites, but the differences in total bacterial numbers were only less than five times. Recent studies demonstrate that soil contains as many as $10^{10}-10^{11}$ bacteria, $6000-50,000$ bacterial species, and up to $200 \mathrm{~m}$ of fungal hyphae per $1 \mathrm{~g}$ and the soil microbes play key roles in ecosystems (van der Heijden et al. 2008).

In addition to soil, plants harbor a diverse and an abundant microbial community and support their activities as the key primary producers in most terrestrial ecosystems. In particular, the rhizosphere, defined as the soil environment influenced by the presence and activities of plant roots, has a huge impact on soil microbes. Plant roots release organic matter called rhizodeposition or root exudate, and the amount of rhizodeposition represents ca. $11 \%$ of carbon fixed by the plant and $27 \%$ of carbon allocated to roots (Dennis et al. 2010). Rhizodeposition supports the microbial activities in the rhizosphere. A wide range of organisms, i.e., different kinds of bacteria, fungi, protozoa, and nematodes, show higher populations in the rhizosphere than in the non-rhizosphere, which is not affected by plant roots. The rhizosphere consists of endorhizosphere (root tissue area), rhizoplane (root surface), and exorhizosphere (rhizosphere soil: soil directly surrounding the root). According to a report summarizing the results of 22 different plants, the numbers of aerobic bacteria were on average 9.9 times (2.6-24.2) higher in rhizosphere soil than in non-rhizosphere soil (Lochhead and Rouatt 1955), and microbial densities are markedly higher in the rhizoplane than in the endorhizosphere. An example showed that the numbers of total bacteria, Gram-negative bacteria, and fungi were 100-1000 times higher in the rhizoplane than in the endorhizosphere (Fig. 15.1). Rhizosphere soil and the rhizoplane are microbial hot spots, and many microbes colonize even the endorhizosphere.

In addition to belowground, the aboveground parts of plants also support a variety of bacteria, yeasts, and fungi. According to Lindow and Brandl (2003), bacteria are by far the most numerous colonists of leaves, ranging from $10^{6}$ to $10^{7}$ cells cm $\mathrm{cm}^{-2}$ (up to $10^{8}$ cells $\mathrm{g}^{-1}$ ). The aerial habitat colonized by these microbes is termed the phyllosphere, and the inhabitants are called epiphytes. The number of epiphytes is affected by surrounding environments. For example, Enya et al. (2007) compared the number of leaf-associated bacteria between field-grown and greenhouse-grown tomato leaves and found that the former harbored 100 times higher densities and the population densities increased with age. Since sago palm grows under field conditions, its leaves and stems are colonized by many microbes.

Microbes affect plant productivity through different mechanisms. First, a typical one is direct effects on plants via plant-associated organisms that form mutualistic or pathogenic relationships with plants. Another is indirect effects via the action of free-living microbes that alter rates of nutrient supply and the partitioning of resources (van der Heijden et al. 2008). Plant productivity is enhanced by different microbial actions, while there are a number of microbial threats to crop production (Table 15.1).

Nitrogen-fixing bacteria contribute to plant productivity to the largest extent, as described below. Arbuscular mycorrhizal (AM) fungi enhance plant productivity, especially in grasslands (van der Heijden et al. 1998). These two symbiotic micro- 


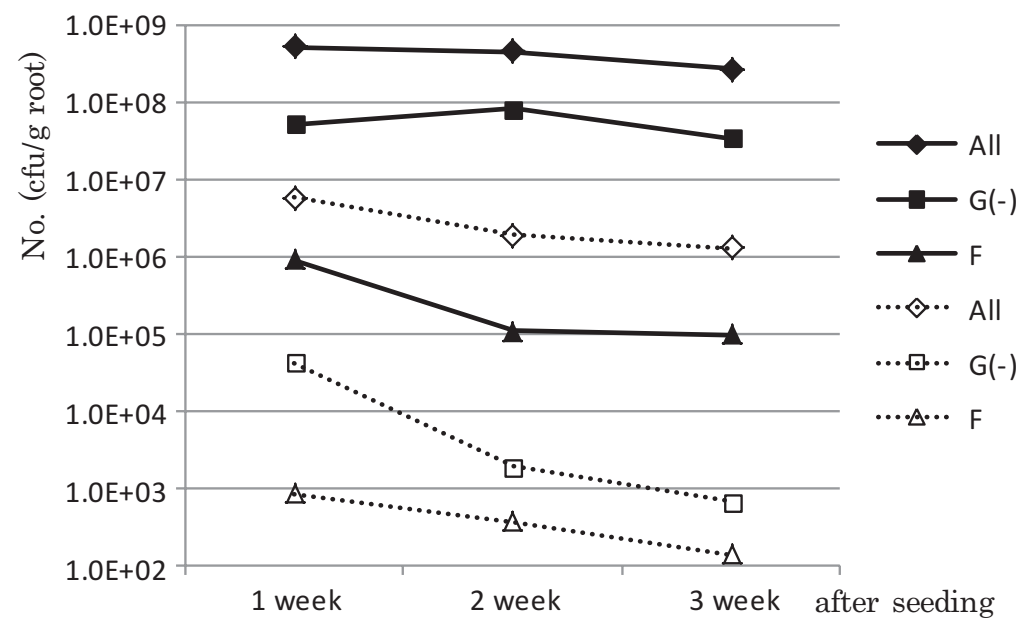

Fig. 15.1 The number of microorganisms in the rhizoplane and endorhizosphere of radish grown in soil. Solid lines, rhizoplane; dotted line, endorhizosphere. All: total culturable bacteria, $G(-)$ Gram-negative bacteria, $F$ fungi (Toyota et al. unpublished data)

Table 15.1 Influence of soil microbes on various ecosystem processes (From van der Heijden et al. 2008)

\begin{tabular}{|c|c|c|}
\hline Ecosystem process & Microbes involved & $\begin{array}{l}\text { Estimated microbial contribution } \\
\text { to ecosystem process }\end{array}$ \\
\hline \multirow[t]{2}{*}{ Plant productivity } & $\begin{array}{l}\text { Nitrogen-fixing bacteria, } \\
\text { mycorrhizal fungi }\end{array}$ & $0-50 \%$ \\
\hline & Microbial pathogens & $-50-0 \%$ \\
\hline Decomposition & Bacteria, fungi & Up to $100 \%$ \\
\hline Plant acquisition $\mathrm{N}$ fixation & $\begin{array}{l}\text { Rhizobia, actinomycetes, } \\
\text { free-living bacteria }\end{array}$ & 0-20\% (sometimes higher) \\
\hline Soil uptake & Mycorrhizal fungi & $0-80 \%$ \\
\hline Nitrogen loss denitrification & $\begin{array}{l}\text { Denitrifying bacteria and } \\
\text { some fungi }\end{array}$ & Up to $60 \%$ \\
\hline $\begin{array}{l}\text { Enhanced leaching because } \\
\text { of nitrification }\end{array}$ & Nitrifying bacteria, archaea & $? ?$ \\
\hline Phosphorus cycle & \multirow{2}{*}{$\begin{array}{l}\text { Mycorrhizal fungi, } \\
\text { P-solubilizing bacteria }\end{array}$} & \multirow[t]{2}{*}{ 0-90\% } \\
\hline $\begin{array}{l}\text { Plant phosphorus } \\
\text { acquisition }\end{array}$ & & \\
\hline $\begin{array}{l}\text { Phosphorus loss because of } \\
\text { leaching }\end{array}$ & & $? ?$ \\
\hline
\end{tabular}

organisms have the greatest impact on plant productivity, but such symbiotic interactions have not been reported in sago palm.

Nutrient supply is an important function of soil microbes. Usually, plants do not use organic forms of $\mathrm{N}$, the dominant form in soil, but use inorganic $\mathrm{N}$, which is mineralized by the actions of soil microbes and animals. Even in agricultural crops 


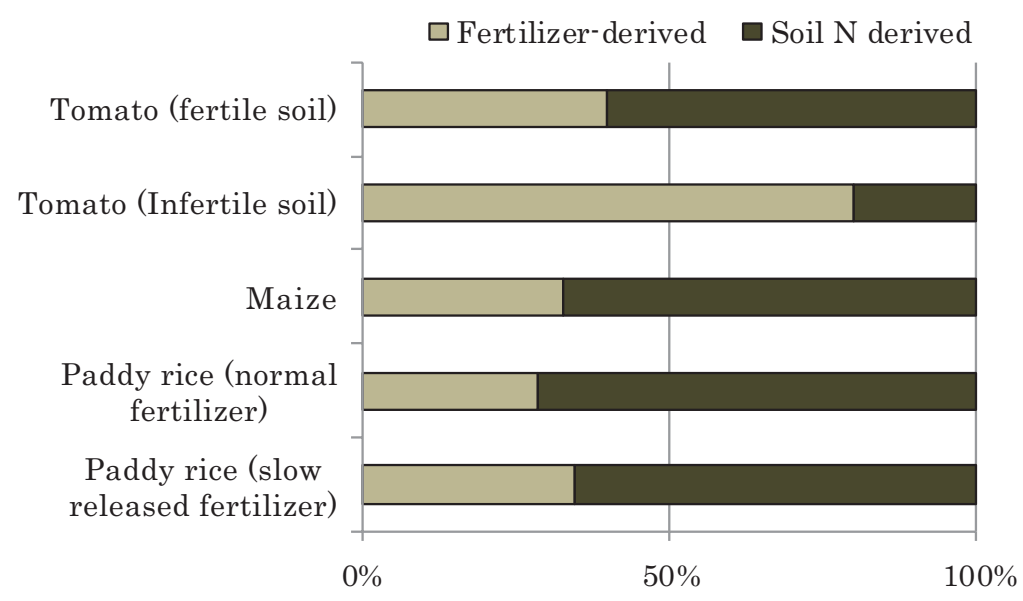

Fig. 15.2 Origin of N uptake by crops (Drawn from Fujiwara et al. 1996, paddy rice; Brady and Weil 2008, maize; Kato 2004, tomato)

where fertilization is always done, crops absorb more $\mathrm{N}$ from the soil organic matter fraction than from applied fertilizer (Fig. 15.2). Since sago palm is often cultivated under non-fertilized conditions, the most important mechanism for its $\mathrm{N}$ acquisition is the mineralization of soil organic matter by soil microbes and animals. Indeed, a pot experiment conducted in a glasshouse showed that sago palm growth evaluated by its plant height did not appear to be affected by urea fertilization (Lina et al. 2010), suggesting the importance of the nutrient-supplying capacity of soil.

Direct yield losses caused by pathogens, insects, and weeds are estimated to range from 20 to $40 \%$ of global agricultural productivity (Savary et al. 2012). In the natural environment, there are many airborne and soilborne plant pathogens, including fungi, bacteria, viruses, and nematodes. On the other hand, many studies have reported biological control of plant pathogens by epiphytes and rhizosphere microbes.

In sago palm, infestation with the bagworm larvae (Pteroma pendula) was found in the Philippines, but its damage to plant productivity was not estimated (Okazaki et al. 2012). As far as the author knows, there is no study reporting damage to sago palm caused by pathogens.

\subsection{Importance of Biological N Fixation}

Biologically fixed $\mathrm{N}$ is a free and renewable resource that plays a key role in sustainable agriculture. Biological $\mathrm{N}$ fixation (BNF) is seen to a varying degree in the soil environment including various parts of plants grown in soil. The potential for $\mathrm{N}$ fixation exists in any environment capable of supporting the growth of $\mathrm{N}$-fixing bacteria (NFB). The global terrestrial amount of BNF is estimated between 100 and 290 million mt per year (Cleveland et al. 1999), 40-48 million mt per year of which 
is fixed by agricultural crops in fields (Jensen and Nielsen 2003), corresponding to nearly one-half of global fertilizer usage. Symbiotic BNF in leguminous plants is famous, and $\mathrm{N}$-fixing bacterial symbionts of legumes can contribute up to $20 \%$ of all plant $\mathrm{N}$ that is annually acquired by vegetation (Cleveland et al. 1999), and its amount reaches as high as $300 \mathrm{~kg} \mathrm{~N} / \mathrm{ha} / \mathrm{crop}$. In addition to symbiotic relations, $\mathrm{BNF}$ through the activities of free-living $\mathrm{N}$ fixers is often seen in non-leguminous plants, e.g., sugarcane (Urquiaga et al. 1992), rice (Shrestha and Ladha 1996), and sago palm (Shrestha et al. 2006). Free-living $\mathrm{N}$-fixing bacteria, which are ubiquitous in terrestrial ecosystems, can also contribute significantly to the $\mathrm{N}$ budget of some systems. Cleveland et al. (1999) reported free-living N-fixing bacteria fix relatively small amounts of $\mathrm{N}(<3 \mathrm{~kg} \mathrm{~N} / \mathrm{ha} / \mathrm{year})$, but there are studies reporting larger contributions, such as 3.3-7.8 kg N/ha/year in tropical forest ecosystems (Reed et al. 2011) and $150 \mathrm{~kg} \mathrm{~N} / \mathrm{ha} / \mathrm{crop}$ in sugarcane (Dobereiner 1997). In oil palm plantations, legume covers are sometimes used under tree crops for the purpose of weed suppression, soil erosion control, and biological control of insect pests (Agamuthu and Broughton 1985). In addition to these, symbiotic BNF is expected; a report found $0.3-34.2 \mathrm{~kg} \mathrm{~N} / \mathrm{ha}$ fixed by legume covers (Pipai 2014).

\subsection{Taxonomy of N-Fixing Bacteria in Palm Trees}

Many free-living $\mathrm{N}$-fixing bacteria have been reported in different crops (Table 15.2). In sago palm, Shrestha et al. (2006) reported that different genera of N-fixing bacteria, such as Klebsiella pneumoniae, K. oxytoca, Pantoea agglomerans, Enterobacter cloacae, Burkholderia sp., Stenotrophomonas maltophilia, and Bacillus megaterium, were isolated from the root, rachis, petiole, leaflet, bark, and pith collected from sago palms in the Philippines. Enterobacter sp., Klebsiella sp., and Pantoea sp. were isolated from extracted starch (Shrestha et al. 2007). Shipton et al. (2010) also focused on starch extracted from sago palm trees and isolated Enterobacter oryzae, Klebsiella oxytoca, and Cronobacter (former Enterobacter) turicensis as N fixers. They also isolated Pectobacterium (former Erwinia) cypripedii from the rhizosphere of sago palm. Few studies have been done on N-fixing bacteria colonizing palm trees. Except for the studies by Shrestha et al. (2006) and Shipton et al. (2010), Reis et al. (2000) reported that oil palm was colonized by Azospirillum brasilense, A. amazonense, and Herbaspirillum seropedicae, and Tang et al. (2010) reported that A. amazonense was isolated from the root of sago palm and that Burkholderia vietnamiensis and B. kururiensis from the root of nipa palm. The genus Azospirillum is a Gram-negative free-living $\mathrm{N}$-fixing rhizosphere bacterium, and A. amazonense was first isolated from roots and rhizosphere soil of Gramineae, in the Amazon region, Brazil (Steenhoudt and Vanderleyden 2000). Burkholderia vietnamiensis was the only known $\mathrm{N}$-fixing species of this bacterial genus and was first isolated from the rhizospheres of rice, maize, and coffee plants (Santos et al. 2001). Since then, several species have been isolated from the endophytic environment of a wide range of taxonomically unrelated plants such as maize, sorghum, sugarcane, 
Table 15.2 Lists of free-living N-fixing bacteria isolated from different plants

\begin{tabular}{|c|c|}
\hline Plants & Isolated bacteria \\
\hline $\begin{array}{l}\text { Sugarcane } \\
\text { (Saccharum spp.) }\end{array}$ & $\begin{array}{l}\text { Azospirillum sp., Azospirillum brasilense, Azospirillum lipoferum, } \\
\text { Azospirillum amazonense, Azotobacter sp., Beijerinckia indica, Beijerinckia } \\
\text { fluminensis, Burkholderia brasiliensis, Burkholderia tropicalis, Derxia sp., } \\
\text { Enterobacteriaceae, Gluconacetobacter diazotrophicus, Gluconacetobacter } \\
\text { azotocaptans, Herbaspirillum seropedicae, Klebsiella sp., Paenibacillus } \\
\text { azotofixans, Pantoea sp., Vibrio sp. }\end{array}$ \\
\hline Maize (Zea mays) & $\begin{array}{l}\text { A. lipoferum, Azotobacter vinelandii, Bacillus circulans, Burkholderia sp., } \\
\text { B. vietnamiensis, Enterobacter } \mathrm{sp} ., \text { Enterobacter cloacae, Klebsiella } \\
\text { terrigena, P. azotofixans }\end{array}$ \\
\hline $\begin{array}{l}\text { Rice }(\text { Oryza } \\
\text { sativa })\end{array}$ & $\begin{array}{l}\text { A. lipoferum, Azospirillum irakense, Azotobacter } \mathrm{sp} ., \text { B. brasiliensis, } \\
\text { Clostridium sp., E. cloacae, H. seropedicae, K. oxytoca, K. pneumoniae, } \\
\text { Pantoea agglomerans, P. azotofixans, Pseudomonas sp. }\end{array}$ \\
\hline $\begin{array}{l}\text { Wheat (Triticum } \\
\text { spp.) }\end{array}$ & $\begin{array}{l}\text { A. lipoferum, Azotobacter sp., Bacillus sp., E. cloacae, Klebsiella oxytoca, } \\
\text { Klebsiella pneumoniae, P. agglomerans }\end{array}$ \\
\hline $\begin{array}{l}\text { Bahia grass } \\
\text { (Paspalum } \\
\text { notatum) }\end{array}$ & Acetobacter paspali, Acetobacter halopareferans, P. agglomerans \\
\hline $\begin{array}{l}\text { Banana (Musa } \\
\text { spp.) }\end{array}$ & $\begin{array}{l}\text { K. pneumoniae, E. cloacae, } H . \text { seropedicae, Herbaspirillum } \\
\text { rubrisubulbicans }\end{array}$ \\
\hline Cereals & $\begin{array}{l}\text { H. seropedicae, A. lipoferum, A. amazonense, } A \text {. irakense, A. brasilense, } B . \\
\text { brasilense }\end{array}$ \\
\hline Coffee & Gluconacetobacter johannae, G. azotocaptans \\
\hline Dune grass & B. tropicalis, P. agglomerans, Stenotrophomonas maltophilia \\
\hline Forage grasses & H. seropedicae, A. brasilense, A. lipoferum, B. brasiliensis \\
\hline $\begin{array}{l}\text { Kallar grass } \\
\text { (Leptochloa fusca) }\end{array}$ & A. halopareferans, Azoarcus sp., E. cloacae, P. agglomerans \\
\hline Mangrove & Azotobacter chroococcum, A. vinelandii, A. beijerinckii \\
\hline Miscanthus spp. & A. doebereinerae, A. lipoferum, $H$. frisingense \\
\hline Oak & B. megaterium, Pseudomonas putida, P. fluorescence, Xanthomonas oryzae \\
\hline $\begin{array}{l}\text { Oil palm (Elaeis } \\
\text { spp.) }\end{array}$ & A. brasilense, A. amazonense, $H$. seropedicae \\
\hline Pine (Pinus spp.) & Bacillus sp., Burkholderia gladioli, Burkholderia glathei \\
\hline $\begin{array}{l}\text { Pineapple (Ananas } \\
\text { comosus) }\end{array}$ & Acetobacter diazotophicus, $H$. rubrisubulbicans \\
\hline $\begin{array}{l}\text { Sago palm } \\
\text { (Metroxylon sagu) }\end{array}$ & B. megaterium, K. pneumoniae, K. oxytoca, E. cloacae, $P$. agglomerans \\
\hline Spartina & $\begin{array}{l}\text { A. brasilense, A. lipoferum, A. vinelandii, Azotobacter chroococcum, } G . \\
\text { diazotrophicus, Herbaspirillum frisingense, } H \text {. seropedicae, } P \text {. stutzeri }\end{array}$ \\
\hline $\begin{array}{l}\text { Sweet potato } \\
\text { (Ipomoea batatas) }\end{array}$ & Acetobacter diazotrophicus, $P$. agglomerans \\
\hline
\end{tabular}


pineapple, and coffee, and currently nine diazotrophic plant-associated Burkholderia, including B. kururiensis, have been validly described (Wong-Villarreal and Caballero-Mellado 2010). These studies conclude that palm trees harbor $\mathrm{N}$ fixers such as facultative anaerobic enteric bacteria, Burkholderia and Azospirillum, which have been also isolated from major crops, such as rice and maize.

\subsection{Enhancement of N-Fixing Ability by Microbial Interactions}

BNF requires many factors; the most important element among them is a carbon substrate. In symbiotic BNF, abundant substrate is provided through photosynthesis by the host plant, while in free-living BNF, a crucial issue is how to obtain enough substrate for the energy source. For that reason, many free-living $\mathrm{N}$-fixing bacteria are associated with plants. In general, NFB utilizes exclusively simple carbon sources like glucose and sucrose (Haahtela et al. 1983). In contrast, the major carbohydrates in plants are complex carbon sources like cellulose, hemicellulose, and pectin (Lack and Evans 2001). Thus the effects of microbial interactions between NFB and indigenous bacteria, both of which were isolated from sago palm, on BNF were investigated. All NFB isolated from sago palm preferred simple sugars, like glucose, sucrose, and lactate, as their substrate for $\mathrm{N}$ fixation and showed extremely low levels of N-fixing activity in starch, hemicellulose, and pectin-containing media (Fig. 15.3) (Shrestha et al. 2007). N-fixing activity by NFB was markedly enhanced by the consortium of starch-degrading Bacillus sp. strain B1 in a starch medium, although the NFB showed negligible N-fixing activity when inoculated singly (Fig. 15.4). The consortium of hemicellulose-degrading Agrobacterium sp. strain

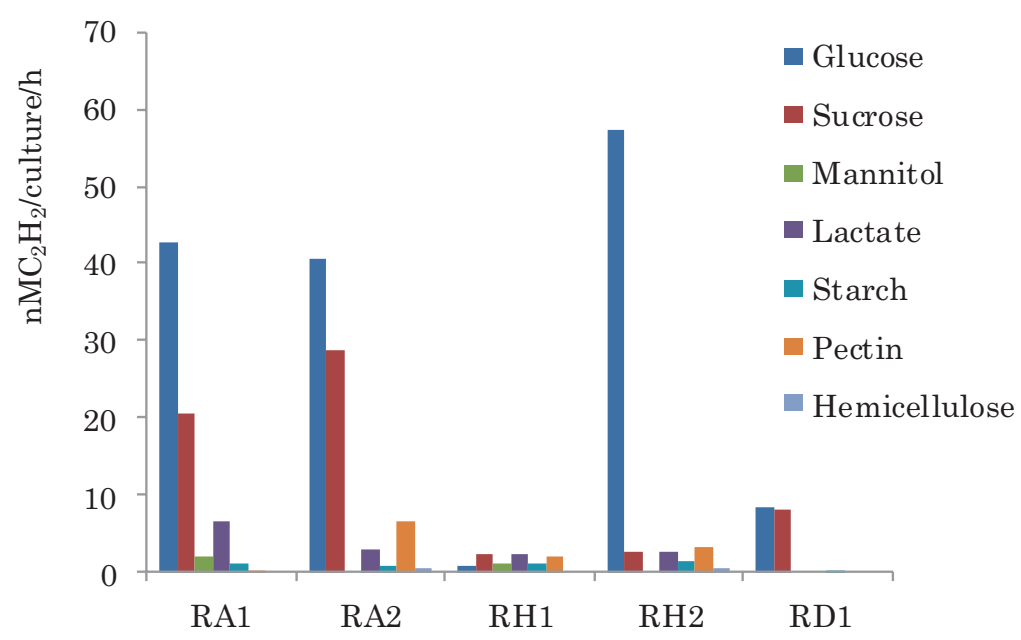

Fig. 15.3 Nitrogen-fixing activity of nitrogen-fixing bacteria in different carbon substrates. Glu glucose, Suc sucrose, Lac lactate, Pec pectin (Shrestha et al. 2007) 

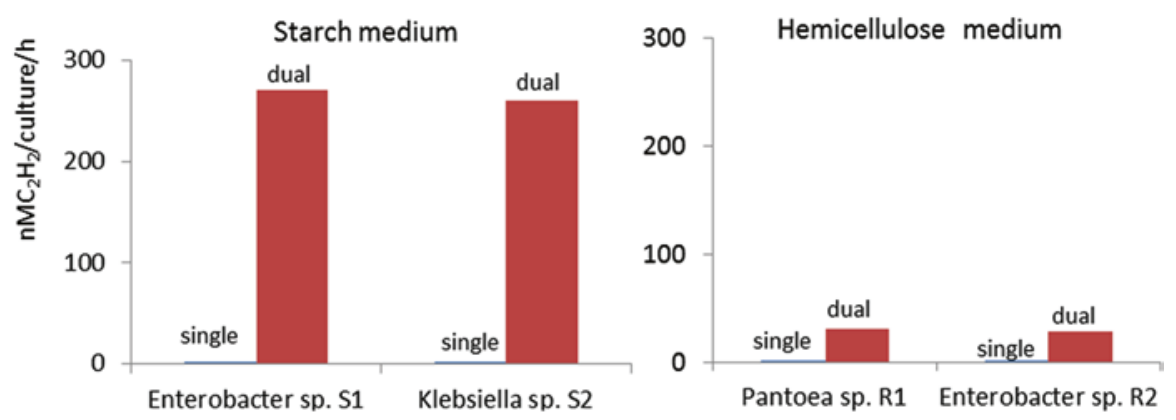

Fig. 15.4 Effect of co-inoculation of nitrogen-fixing bacteria (S1, S2, R1, and R2) and polymerdegrading bacteria on the nitrogen-fixing activity in polymer media (Shrestha et al. 2007)

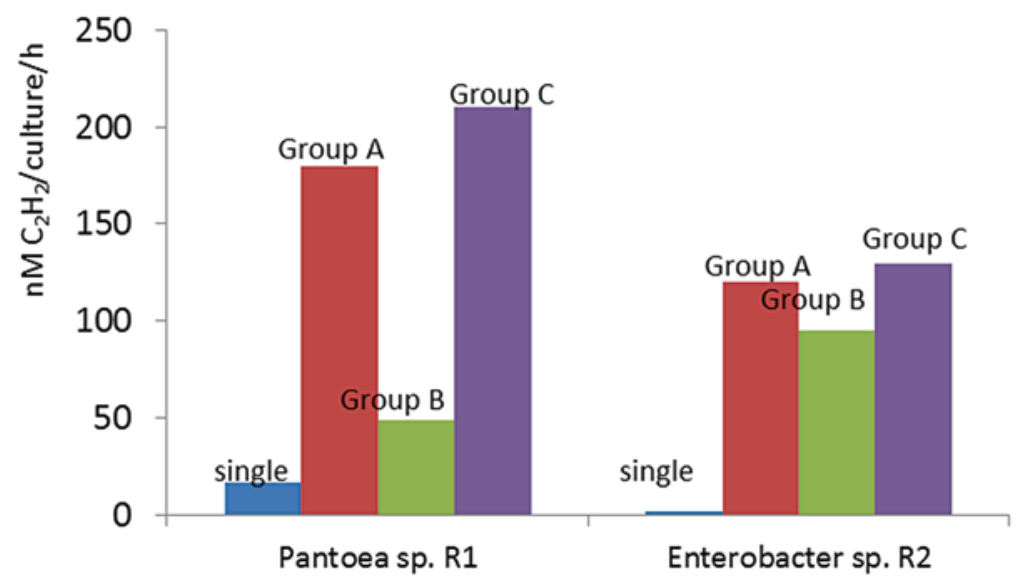

Fig. 15.5 Effects of co-inoculation of randomly isolated strains (each group consisted of ten strains) on nitrogen-fixing ability of nitrogen-fixing bacteria (R1 and R2) (Shrestha et al. 2007)

HMC1 or Flexibacter sp. strain HMC2 and NFB also showed enhanced N-fixing activity in a hemicellulose medium. Such stimulation was not observed in a pectin medium. These results suggest that $\mathrm{N}$-fixing bacteria may actively fix $\mathrm{N}$ in collaboration with degraders of starch and hemicellulose, the major carbohydrates in sago palm plant bodies.

The second important parameter in BNF is an oxygen level which affects nitrogenase activity directly (Robson and Postgate 1980). Coculture of NFB and indigenous bacteria, isolated from sago palm using nutrient agar medium, in a nitrogen-free Rennie medium containing simple organic compounds showed significantly higher $\mathrm{N}$-fixing activity than single inoculations of NFB did in almost all combinations (Fig. 15.5), suggesting that co-inoculated bacteria consumed $\mathrm{O}_{2}$ and made conditions with deficient $\mathrm{O}_{2}$. Indeed, we confirmed that a reduced oxygen status itself enhanced the N-fixing activity of NFB (Fig. 15.6) (Shrestha et al. 2007). 


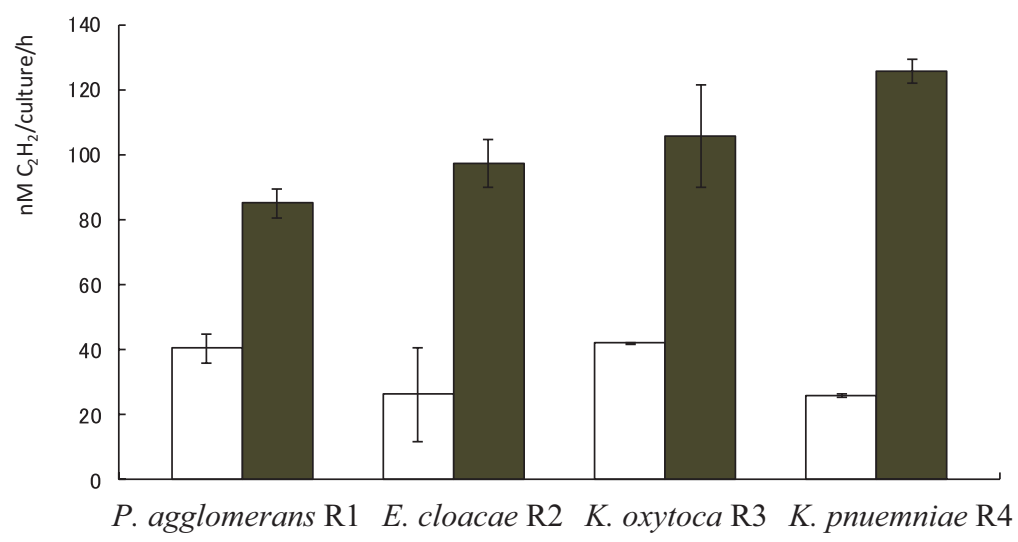

Fig. 15.6 Effect of ambient (white bar) and reduced $\mathrm{O}_{2}$ (gray bar) conditions on the nitrogenfixing activity of selected nitrogen fixers (R1, R2, R3, and R4) (Shrestha et al. 2007)

These results may indicate that beneficial microbial interactions occur in sago palm to enhance $\mathrm{N}$-fixing activity through collaborative utilizations of starch, hemicellulose, and their degradation products.

\subsection{Estimate of Amounts of N Fixation in Palms}

Shrestha et al. $(2006,2007)$ quantified N-fixing activity in different parts of sago palm, such as stem, leaf, root, bark, and starch, and isolated a wide range of $\mathrm{N}$-fixing bacteria. Although the estimation of fixed $\mathrm{N}$ based on the acetylene-reducing activity contains some uncertainties, the amount of fixed $\mathrm{N}$ in a mature sago palm stand was estimated at $210 \mathrm{~kg} \mathrm{~N} / \mathrm{ha} / \mathrm{y}$ from calculation based on $\mathrm{N}$-fixing activity in root (221 nM C ${ }_{2} \mathrm{H}_{4} / \mathrm{g} /$ day), pith (213 $\mathrm{nM} \mathrm{C}_{2} \mathrm{H}_{4} / \mathrm{g} /$ day), and leaf sheath (35.4 nM C ${ }_{2} \mathrm{H}_{4} / \mathrm{g} /$ day) and their mean weights per palm $(68,721$, and $97 \mathrm{~kg}$ in root, pith, and leaf sheath, respectively) with a sago palm density in a mature forest of 923 sago palms/ ha (Toyota 2015).

Yonebayashi et al. (2014) estimated the amount of $\mathrm{N}$ fixation in sago palm using a tracer experiment. They measured $\delta 15 \mathrm{~N}$ values of the youngest leaves of sago palms at different stages of growth and found that $\delta 15 \mathrm{~N}$ values were lower with age, indicating higher $\mathrm{N}$ fixation with maturing. The contribution of biologically fixed $\mathrm{N}$ to total $\mathrm{N}$ of sago palm leaves was less than $10 \%$ at the beginning of growth stage (3 years), but it increased with age and reached more than $90 \%$ at the later stage (13 years).

Amounts of $\mathrm{N}$ fixation have been estimated in other palms. De Carvalho et al. (2008) reported that $13-76 \%$ of total $\mathrm{N}$ in oil palm depended on biological $\mathrm{N}$ fixation in a 1-year growth experiment using $\mathrm{N}$ poor quartz sand and subsoil. Zakry et al. (2012) found that the contribution of biological $\mathrm{N}$ fixation to total $\mathrm{N}$ uptake by oil palm was different depending on the plant parts in oil palm $(75 \%$ in leaflet, $13 \%$ in stem, and $13 \%$ in root) and was $63 \%$ on the whole plant basis. These results reveal that BNF functions as a biofertilizer and is essential in establishing sustainable crop production. 


\section{References}

Agamuthu P, Broughton WJ (1985) Nutrient cycling within the developing oil palm-legume ecosystem. Agric Ecosyst Environ 13:111-123

Brady NC, Weil RR (2008) The nature and properties of soils, 14th edn. Pearson Education Inc, Upper Saddle River, p 573

Cleveland CC, Townsend AR, Schimel DS et al (1999) Global patterns of terrestrial biological nitrogen $\left(\mathrm{N}_{2}\right)$ fixation in natural ecosystems. Glob Biogeochem Cycles 13:623-645

de Carvalho ALV, Alves BJR, Baldani VLD, Reis VM (2008) Application of (15)N natural abundance technique for evaluating biological nitrogen fixation in oil palm ecotypes at nursery stage in pot experiments and at mature plantation sites. Plant Soil 302:71-78

Dennis PG, Miller AJ, Hirsch PR (2010) Are root exudates more important than other sources of rhizodeposits in structuring rhizosphere bacterial communities? FEMS Microbiol Lett 72:313-327

Dobereiner J (1997) Biological nitrogen fixation in the tropics: social and economic contributions. Soil Biol Biochem 29:771-774

Enya J, Shinohara H, Yoshida S et al (2007) Culturable leaf-associated bacteria on tomato plants and their potential as biological control agents. Microb Ecol 53:524-536

Fujiwara S, Anzai T, Kato T (1996) Methods and applications of soil diagnosis. Rural Culture Association Japan, Tokyo, p 141. (in Japanese)

Haahtela KT, Kari K, Sundman V (1983) Nitrogenase activity of root associated, cold climate Azospirillum, Enterobacter, Klebsiella and Pseudomonas species during growth on various sources and at various partial pressures of oxygen. Appl Environ Microbiol 45:563-570

Jensen ES, Hauggaard-Nielsen H (2003) How can increased use of biological N2 fixation in agricultural benefit the environment? Plant Soil 252:177-186

Kato (2004) Encyclopedia of vegetables and horticulture 22 hydroponics. Rural Culture Association Japan, Tokyo, p 429. (in Japanese)

Lack AJ, Evans DE (2001) The plant cell wall. In: Hames BD (ed) Instant notes: plant biology. BIOS Scientific Publishers Limited, Milton Park, pp 6-7

Lina SB, Okazaki M, Kimura SD et al (2010) Nitrogen uptake and growth response of sago palm (Metroxylon sagu Rottb.) to two types of urea fertilizer application. Sago Palm 18:73-83

Lindow SE, Brandl MT (2003) Microbiology of the phyllosphere. Appl Environ Microbiol 69:1875-1883

Lochhead AG, Rouatt JW (1955) The "rhizosphere effect" on the nutritional groups of soil bacteria. Soil Sci Soc Am J 19:48-49

Mishustin EN, Mirsoeva VA (1968) Spore forming bacteria in the soils of USSR. In: Gray TRG, Parkinson D (eds) The ecology of soil bacteria. University Press, Liverpool, pp 458-473

Okazaki M, Kimura SD, Suzette LB et al (2012) Pteroma pendula infestation of sago palm (Metroxylon sagu Rottb.) in Leyte, Philippines. Sago Palm 20:69-75

Pipai R (2014) Biological nitrogen fixation by cover legumes under oil palm plantations in Papua New Guinea. Master of Agricultural Science thesis, The University of Adelaide

Reed SC, Cleveland CC, Townsend AR (2011) Functional ecology of free-living nitrogen fixation: a contemporary perspective. Annu Rev Ecol Evol Syst 42:489-512

Reis VM, Baldani JI, Baldani VLD, Dobereiner J (2000) Biological dinitrogen fixation in Gramineae and palm trees. Crit Rev Plant Sci 19:227-247

Robson RL, Postgate JR (1980) Oxygen and hydrogen in biological nitrogen fixation. Annu Rev Microbiol 34:183-207

Santos PEDL, Bustillos-Cristales R, Caballero-Mellado J (2001) Burkholderia, a genus rich in plant-associated nitrogen fixers with wide environmental and geographic distribution. Appl Environ Microbiol 67:2790-2798

Savary S, Ficke A, Aubertot JN, Hollier C (2012) Crop losses due to diseases and their implications for global food production losses and food security. Food Sec 4:519-537 
Shipton WA, Baker A, Blaney BJ et al (2010) Nitrogen fixation associated with sago (Metroxylon sagu) and some implications. Lett Appl Microbiol 52:56-61

Shrestha RK, Ladha JK (1996) Genotypic variation in promotion of rice nitrogen fixation as determined by nitrogen ${ }^{15} \mathrm{~N}$ dilution. Am J Soil Sci 60:1815-1821

Shrestha A, Toyota K, Nakano Y et al (2006) Nitrogen fixing activity in different parts of sago palm (Metroxylon sagu) and characterization of aerobic nitrogen fixing bacteria colonizing sago palm. Sago Palm 14:20-32

Shrestha A, Toyota K, Okazaki M et al (2007) Enhancement of nitrogen-fixing activity of Enterobacteriaceae strains isolated from sago palm (Metroxylon sagu) by microbial interaction with non-nitrogen fixers. Microbes Environ 22:59-70

Steenhoudt O, Vanderleyden J (2000) Azospirillum, a free-living nitrogen-fixing bacterium closely associated with grasses: genetic, biochemical and ecological aspects. FEMS Microbiol Rev 24:487-506

Tang SY, Hara S, Melling L et al (2010) Burkholderia vietnamiensis isolated from root tissues of nipa palm (Nypa fruticans) in Sarawak, Malaysia, proved to be its major endophytic nitrogenfixing bacterium. Biosci Biotechnol Biochem 74:1972-1975

Toyota K (2015) Nitrogen fixing bacteria. In: Society of Sago Palm Studies (ed) The sago palm: the food and environmental challenges of the 21 st century. Kyoto University Press, Kyoto, pp 150-155

Urquiaga S, Cruz KHS, Boddey RM (1992) Contribution of nitrogen-fixation to sugar cane: nitrogen-15 and nitrogen-balance estimates. Soil Sci Soc Am 56:105-114

van der Heijden MGA, Klironomos JN, Ursic M et al (1998) Mycorrhizal fungal diversity determines plant biodiversity, ecosystem variability and productivity. Nature 396:69-72

van der Heijden MGA, Bardgett RD, van Straalen NM (2008) The unseen majority: soil microbes as drivers of plant diversity and productivity in terrestrial ecosystems. Ecol Lett 11:296-310

Wong-Villarreal A, Caballero-Mellado J (2010) Rapid identification of nitrogen-fixing and legumenodulating Burkholderia species based on PCR 16S rRNA species-specific oligonucleotides. Syst Appl Microbiol 33:35-43

Yonebayashi K, Katsumi N, Nishi T, Okazaki M (2014) Activation of nitrogen-fixing endophytes is associated with the tuber growth of sweet potato. Mass Spectrom 3:A0032

Zakry FAA, Shamsuddin ZH, Rahim KA et al (2012) Inoculation of Bacillus sphaericus UPMB10 to young oil palm and measurement of its uptake of fixed nitrogen using the ${ }^{15} \mathrm{~N}$ isotope dilution technique. Microbes Environ 27:257-262

Open Access This chapter is licensed under the terms of the Creative Commons Attribution 4.0 International License (http://creativecommons.org/licenses/by/4.0/), which permits use, sharing, adaptation, distribution and reproduction in any medium or format, as long as you give appropriate credit to the original author(s) and the source, provide a link to the Creative Commons license and indicate if changes were made.

The images or other third party material in this chapter are included in the chapter's Creative Commons license, unless indicated otherwise in a credit line to the material. If material is not included in the chapter's Creative Commons license and your intended use is not permitted by statutory regulation or exceeds the permitted use, you will need to obtain permission directly from the copyright holder. 